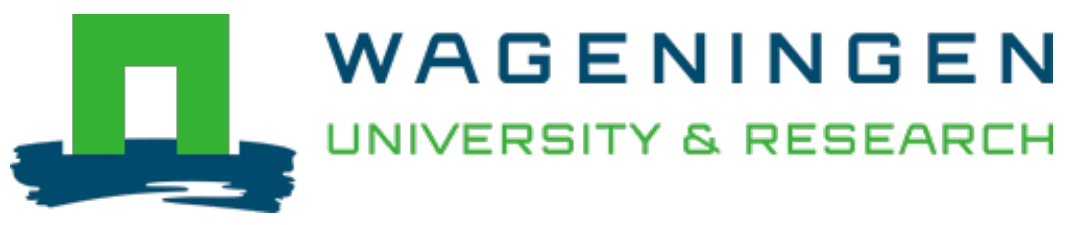

\title{
Macroinvertebrate taxonomic and trait-based responses to large-wood reintroduction in lowland streams
}

\author{
Freshwater Science \\ Brouwer, Jan H.F.; Verdonschot, Piet F.M.; Eekhout, Joris P.C.; Verdonschot, Ralf C.M. \\ https://doi.org/10.1086/710710
}

This publication is made publicly available in the institutional repository of Wageningen University and Research, under the terms of article $25 \mathrm{fa}$ of the Dutch Copyright Act, also known as the Amendment Taverne. This has been done with explicit consent by the author.

Article 25 fa states that the author of a short scientific work funded either wholly or partially by Dutch public funds is entitled to make that work publicly available for no consideration following a reasonable period of time after the work was first published, provided that clear reference is made to the source of the first publication of the work.

This publication is distributed under The Association of Universities in the Netherlands (VSNU) 'Article $25 \mathrm{fa}$ implementation' project. In this project research outputs of researchers employed by Dutch Universities that comply with the legal requirements of Article $25 \mathrm{fa}$ of the Dutch Copyright Act are distributed online and free of cost or other barriers in institutional repositories. Research outputs are distributed six months after their first online publication in the original published version and with proper attribution to the source of the original publication.

You are permitted to download and use the publication for personal purposes. All rights remain with the author(s) and / or copyright owner(s) of this work. Any use of the publication or parts of it other than authorised under article $25 \mathrm{fa}$ of the Dutch Copyright act is prohibited. Wageningen University \& Research and the author(s) of this publication shall not be held responsible or liable for any damages resulting from your (re)use of this publication.

For questions regarding the public availability of this publication please contact openscience.library@wur.nl 


\title{
Macroinvertebrate taxonomic and trait-based responses to large-wood reintroduction in lowland streams
}

\author{
Jan H. F. de Brouwer ${ }^{1,4}$, Piet F. M. Verdonschot ${ }^{1,2,5}$, Joris P. C. Eekhout ${ }^{3,6}$, and Ralf C. M. Verdonschot ${ }^{1,7}$ \\ ${ }^{1}$ Wageningen Environmental Research, Wageningen University and Research, P.O. Box 47, 6700 AA Wageningen, The Netherlands \\ ${ }^{2}$ Institute for Biodiversity and Ecosystem Dynamics, University of Amsterdam, P.O. Box 94240, 1090 GE Amsterdam, The Netherlands \\ ${ }^{3}$ Soil and Water Conservation Research Group, Spanish National Research Council, P.O. Box 164, 30100 Murcia, Spain
}

\begin{abstract}
In hydromorphologically-degraded lowland streams, large-wood reintroductions are often used to reestablish instream physical structure, which might also increase biodiversity. However, the success rate of this approach varies in terms of positive macroinvertebrate assemblage responses. To obtain better insight into macroinvertebrate-wood relationships, we studied macroinvertebrate assemblage composition and its associated ecological and functional traits in 3 lowland streams in The Netherlands where wood was reintroduced. We used a before-after control-impact design in which we studied stream sections in 3 y: 1 y before and 2 y after large wood was added to some stream sections but not others. We recorded changes in physical structure expressed as substrate diversity, complexity, patchiness, and stability and then compared these parameters within and among the control and treated sections in each stream. We also sampled macroinvertebrates to determine whether the assemblage composition changed because of the wood addition. Finally, we assessed whether changes in macroinvertebrate assemblage could be related to taxa preferences for substrate type and flow and to their functional traits related to mode of locomotion and feeding type. Habitat heterogeneity increased after the wood additions and was relatively stable between years. Macroinvertebrate assemblages changed relative to the control sections in the $2 \mathrm{y}$ after introduction, with 50 to $58 \%$ of the taxa increasing or decreasing significantly in abundance. Despite the changes in substrate composition and habitat heterogeneity, most of the functional relationships we expected between macroinvertebrates and large wood were either not apparent or site specific. The only characteristic shared by the macroinvertebrates that consistently increased in response to wood additions was a high affinity for hard substrates. In 1 stream we also observed an increase in taxa with a preference for high-flow velocity and a grazer-scraper feeding mode. These findings suggest that an increase in the surface area of stable, hard substrate was the main underlying ecological effect of reintroducing large wood to the stream channel of sand-bed lowland streams, at least in the short term, and that this change only affected a specific part of the macroinvertebrate assemblage. Changes in assemblage composition occurred primarily during the $1^{\text {st }} \mathrm{y}$ after the wood additions and decreased between the $1^{\text {st }}$ and $2^{\text {nd }} y$, so colonization in this early successional stage seems to be limited to the species pool present in the immediate surroundings.
\end{abstract}

Key words: stream restoration, benthic invertebrates, traits, habitat heterogeneity, colonization

Large wood in streams is a key hydromorphological component that, to a large extent, shapes the instream environment (Gerhard and Reich 2000, Gurnell et al. 2002). Large wood can influence macroinvertebrate occurrence and abundance by providing habitat substrate, food, and shelter, among other things (Hax and Golladay 1998, Collier and Halliday 2000, Benke and Wallace 2003, Scealy et al. 2007). Therefore, it is not surprising that the common practice of removing large wood from streams, as well as reduced wood inputs due to the clearing of riparian forests, negatively affects the structure

E-mail addresses: ${ }^{4}$ j.debrouwer@accuralis.com; ${ }^{5}$ piet.verdonschot@wur.nl; ${ }^{6}$ joriseekhout@gmail.com; ${ }^{7}$ To whom correspondence should be addressed: ralf.verdonschot@wur.nl

DOI: 10.1086/710710. Received 28 June 2019; Accepted 1 November 2019; Published online 16 October 2020; Associate editor, Keith Gido. Freshwater Science. 2020. 39(4):693-703. ๑ 2020 by The Society for Freshwater Science. 
and functioning of stream ecosystems (Angermeier and Karr 1984, Lepori et al. 2005, Schinegger et al. 2012).

During the last few decades, reintroduction of large wood has become a widespread restoration measure used to reestablish instream physical structure and improve biodiversity (Kail et al. 2007, Lester et al. 2007, Roni et al. 2015, Grabowski et al. 2019). Reintroducing large wood increases hydraulic variation and contributes to a more-diverse physical substrate composition (Gippel et al. 1996) by trapping coarse particulate organic matter (CPOM) in net-like wood patches (Koljonen et al. 2012). The logs and branches cause changes in streams' physical structure and flow patterns by forming pools, riffles, dams, and patches with particulate organic matter or mineral material (Harmon et al. 1986, Gerhard and Reich 2000). Furthermore, wood patches increase resistance against high-flow velocities and thereby facilitate retention of water in upstream reaches, which leads to less-frequent low flows and the leveling off of peak flows in the downstream reaches (Gippel 1995).

The response of macroinvertebrate density and diversity to the addition of large wood varies and may depend on sitespecific environmental conditions, time since introduction, and characteristics of the wood (e.g., Gerhard and Reich 2000, Benke and Wallace 2003, Johnson et al. 2003, Scealy et al. 2007). For example, in their review on the effects of introduced large wood, Roni et al. (2015) found that $\sim 1 / 2$ of 21 studies that measured macroinvertebrate responses found no change or negative changes in density or diversity. To optimize future restoration efforts, it is important to pinpoint the factors that underlie these contrasting responses.

This study focuses on determining the relationship between wood-patch physical structure and macroinvertebrate taxonomic and functional composition in terms of diversity, complexity, the level of patchiness, and patch stability. We studied macroinvertebrate assemblages in stream sections before and after the introduction of large wood in 3 lowland streams in The Netherlands. We compared the temporal changes in stream sections with large-wood additions to temporal changes in unrestored control sections to evaluate the effects of wood additions on stream and macroinvertebrate characteristics.

We hypothesized that large-wood additions would improve instream physical structure in all 3 streams by increasing the substrate diversity, the degree of habitat complexity, and the number of different habitat patches present in a given stream section (Fig. 1A, B). The presence of large wood in streams offers additional attachment and feeding opportunities for macroinvertebrates, so these additions should influence the ecological and functional traits of the macroinvertebrate assemblages that occur in the streams (Benke and Wallace 2003, Lester et al. 2007). Therefore, we expected large-wood additions to result in an increase in taxa with an affinity for hard substrate types, fast flowing conditions, passive filter-feeder and scraper-grazer feeding modes, or a semi-sessile mode of locomotion. Besides the wood-patch structures themselves, increased CPOM retention within the wood patches should provide additional habitat for detritivores, which we expected to result in an increase in the shredder feeding mode and a preference for patches of particulate organic matter (detritus). Finally, we expected that the increased complexity of substrate would result in a higher number of predators.

\section{METHODS \\ Study design}

We examined the effects of physical structures on macroinvertebrate assemblages in 3 lowland streams in The Netherlands. Watershed managers had already planned largewood introductions as part of larger watershed restoration projects in streams Hierden, Tongelreep, and Tungelroy (Table 1). All of these streams had experienced eutrophication, increases in peak discharge, degradation of the riparian zone, and excessive maintenance of the stream channel (e.g., removal of large wood and vegetation). Large-wood additions were carried out as an instream restoration measure aimed at increasing habitat availability for biota. Among-stream comparisons were facilitated by applying a large-wood introduction protocol to guide the watershed managers responsible for the implementation, resulting in a similar layout of the large-wood patches in the different streams.

These streams also had similar environmental conditions including bankfull width, stream-valley land use and discharge, and stream type. They all belonged to the low-gradient sand-bed stream type, according to the Dutch Water Framework Directive stream typology categorization (van der Molen et al. 2019). This consistency indicates that the variation in biotic and abiotic conditions among streams falls within the environmental boundaries established for this stream type and was distinctive from that of other stream types (Hering et al. 2004), facilitating comparisons among streams. Nonetheless, we analyzed the 3 streams separately to account for potential effects of differences in environmental conditions. For example, the more-open canopy of stream Tungelroy resulted in extensive macrophyte growth, which was absent in the heavily shaded stream Hierden. This difference might influence physical structure and associated macroinvertebrate assemblages.

We used a before-after control-impact (BACI) design to study the effects of the large-wood additions. We compared 500 - $\mathrm{m}$ reaches ( $1 \mathrm{reach} /$ stream) where wood patches were introduced with adjacent upstream 500-m-control reaches (1 reach/stream) with similar environmental conditions. Inter-reach distance was $\sim 100 \mathrm{~m}$. Although downstream reaches were not fully independent from upstream reaches, this design maximized similarity of macroinvertebrate assemblages and environmental conditions in the sampled reaches, which aided in determining the impact of the wood additions.

In autumn 2010, we sampled both the control and the impact reaches at each site (before treatment). We randomly 
Changes in physical structure after introduction of large wood

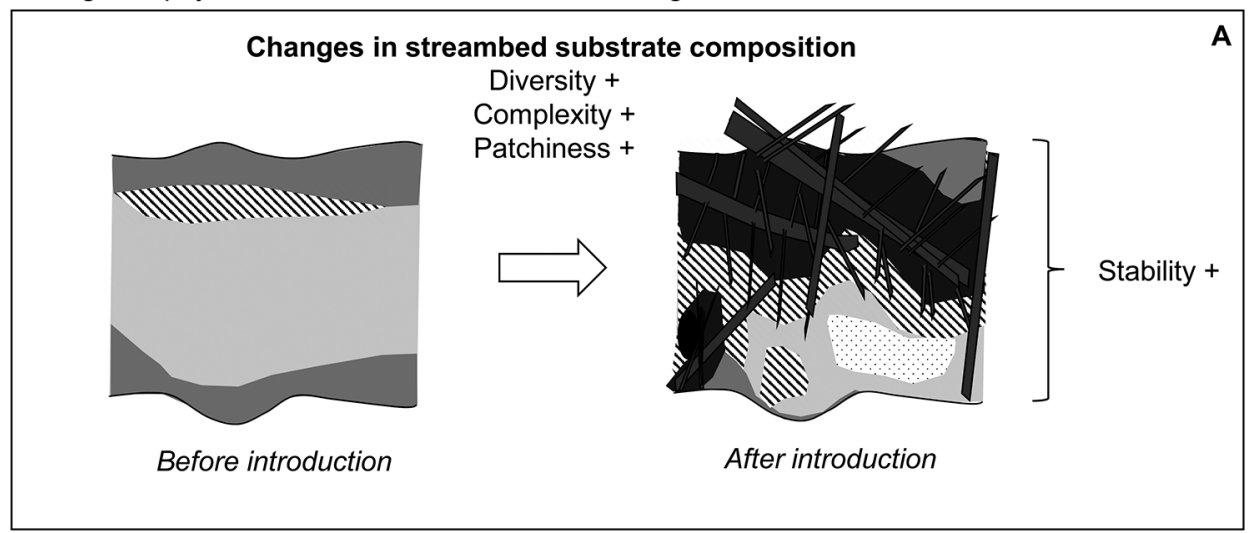

Ecological and functional response of macroinvertebrate communities

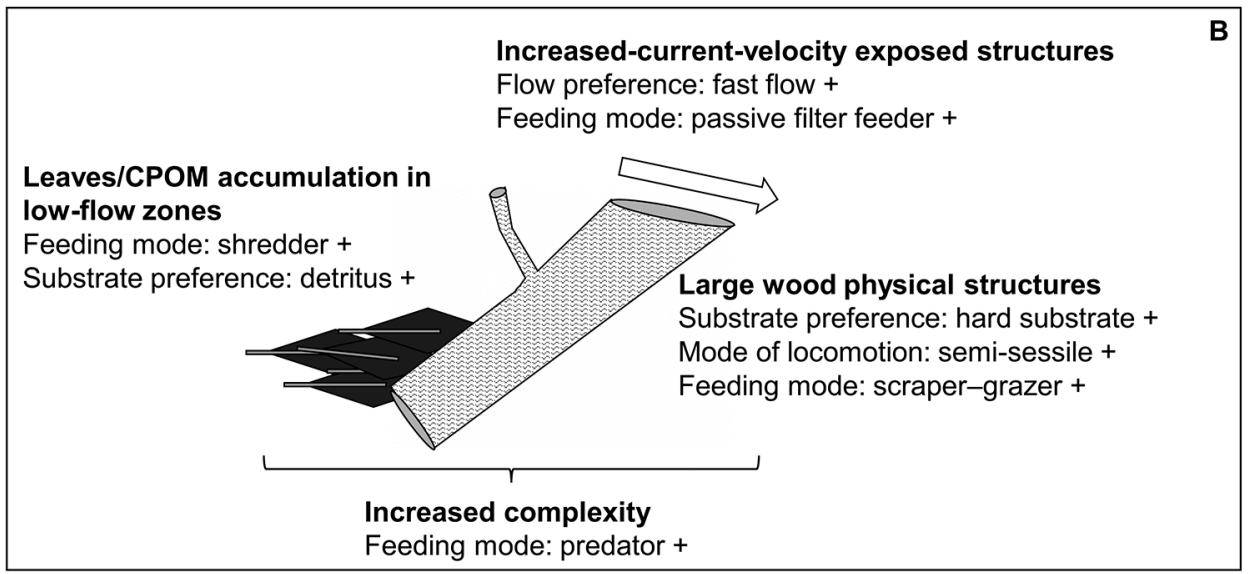

Figure 1. Conceptual diagram illustrating the predicted changes in streambed substrate physical structure (A) and trait-based response (B) of the macroinvertebrate assemblages after large wood was added to the stream channel. + indicates an increase.

selected three 20-m sections within each reach, determined their physical structure, and collected macroinvertebrate samples in each section (see Sampling for methods). After the introduction of large wood in winter (Tongelreep: December 2010, Hierden and Tungelroy: February 2011), we sampled in autumn to early winter in 2011 ( 1 y after treatment) and 2012 (2 y after treatment). After the wood additions, all sampled impact sections contained a large-wood patch. These wood patches covered areas of 25 to $50 \mathrm{~m}^{2}$ (patch length 10-15 $\mathrm{m}$ ) and consisted of interwoven logs

Table 1. Site characteristics for the 3 stream reaches used in the study. Land use, the reach length with wood patches, and the number of wood patches/reach are given. Hydromorphological characteristics include the minimum and maximum bankfull width of the reach, the average $( \pm \mathrm{SD})$ maximum water depth, the reach gradient, average $( \pm \mathrm{SD})$ flow velocity, and average annual discharge. Chemical characteristics include the yearly average total nitrogen (TN) concentration and the yearly average total phosphorous (TP) concentration.

\begin{tabular}{|c|c|c|c|c|c|c|c|c|c|c|c|}
\hline Site & Coordinates & Land use & $\begin{array}{l}\text { Reach } \\
\text { length } \\
(\mathrm{km})\end{array}$ & $\begin{array}{l}\text { Patches } \\
\text { (no.) }\end{array}$ & $\begin{array}{l}\text { Width } \\
(\mathrm{m})\end{array}$ & $\begin{array}{l}\text { Depth } \\
(\mathrm{m})\end{array}$ & $\begin{array}{l}\text { Gradient } \\
(\mathrm{m} / \mathrm{km})\end{array}$ & $\begin{array}{c}\text { Flow } \\
\text { velocity } \\
(\mathrm{m} / \mathrm{s})\end{array}$ & $\begin{array}{c}\text { Discharge } \\
\left(\mathrm{m}^{3} / \mathrm{s}\right)\end{array}$ & $\begin{array}{c}\mathrm{TN} \\
(\mathrm{mg} / \mathrm{L})\end{array}$ & $\begin{array}{c}\mathrm{TP} \\
(\mathrm{mg} / \mathrm{L})\end{array}$ \\
\hline Hierden & $\begin{array}{c}51^{\circ} 19^{\prime} 51.64^{\prime \prime} \mathrm{N} \\
5^{\circ} 42^{\prime} 41.45^{\prime \prime} \mathrm{E}\end{array}$ & Forest & 0.9 & 15 & $5-7$ & $0.6(0.2)$ & 1.9 & $0.19(0.10)$ & 0.3 & 5.97 & 0.11 \\
\hline Tongelreep & $\begin{array}{c}51^{\circ} 22^{\prime} 27.01^{\prime \prime} \mathrm{N} \\
5^{\circ} 29^{\prime} 33.03^{\prime \prime} \mathrm{E}\end{array}$ & Forest & 0.7 & 6 & $6-7$ & $0.6(0.2)$ & 0.4 & $0.24(0.10)$ & 1 & 3.27 & 0.25 \\
\hline Tungelroy & $\begin{array}{c}51^{\circ} 14^{\prime} 27.67^{\prime \prime} \mathrm{N} \\
5^{\circ} 54^{\prime} 57.33^{\prime \prime} \mathrm{E}\end{array}$ & $\begin{array}{l}\text { Grassland } \\
\text { and forest }\end{array}$ & 0.5 & 9 & $7-9$ & $1.0(0.4)$ & 0.5 & $0.19(0.13)$ & 1.1 & 2.46 & 0.27 \\
\hline
\end{tabular}


(diameter $>20 \mathrm{~cm}$ ) and branches (diameter $>5 \mathrm{~cm}$ ) that covered the full width of the stream (Fig. S1). The internal structure of wood patches was open, allowing water to flow through the patches at median discharge and over the patches during spates. In terms of substrate cover, the large wood covered 20 to $25 \%$ of the stream bed immediately after introduction. Inter-patch distance ranged from 25 to $40 \mathrm{~m}$.

\section{Sampling}

Physical structure For each 20-m section, we visually estimated the proportional cover of the dominant $(>5 \%$ coverage in a given section) streambed substrates. We classified the substrates following Hering et al. (2003): sand (including sand and mineral mud with a grain size of $6 \mu \mathrm{m}-2 \mathrm{~mm}$ ), wood (including large wood, branches, twigs), leaves (freshly fallen), CPOM (e.g., leaf fragments), fine particulate organic matter (FPOM), macrophytes, filamentous algae, and gravel (fine-medium with grain size of $0.2-2 \mathrm{~cm}$ ).

Macroinvertebrates Macroinvertebrate sampling was carried out in the same 3 impact and control sections/stream surveyed for substrate cover before and after large-wood additions. We collected macroinvertebrates with a Surber sampler $(25 \times 25 \mathrm{~cm}, 1$-mm mesh) by taking 5 subsamples from the dominant substrates present in each 20 -m section, which we pooled to form 1 representative multi-habitat sample of $0.3 \mathrm{~m}^{2}$ for each section. We sampled large wood by lightly brushing the wood surface with a stiff-bristle brush (area sampled similar to the surface area of the Surber sampler). Macroinvertebrate samples were taken to the laboratory and sorted alive. We identified specimens to the lowest practical taxonomic level, generally species or genus.

\section{Statistical analyses}

Physical structure We defined the spatial component of physical structure by 3 parameters: habitat diversity, complexity, and patchiness. We calculated habitat diversity with Simpson's diversity index (Hill 1973), habitat diversity $=1 /$ $\sum\left(P_{i}\right)^{2}$, where $P_{i}$ is the proportion of the $i^{\text {th }}$ substrate type. We calculated habitat complexity by substituting the relative proportion of each substrate type with a habitat-complexity class in the equation of habitat diversity. Habitat-complexity classes ranged from 1 for simple structures to 3 for complex structures. We defined sand, gravel, and FPOM as class 1; leaves, CPOM, and algae as class 2; and wood and macrophytes as class 3 . We calculated habitat patchiness as the standard deviance of the percentage of each substrate cover divided by its mean percentage and multiplied by the total number of patches recorded (Eadie and Keast 1984). We determined habitat stability, the temporal component of physical structure, by calculating the Bray-Curtis dissimilarity of the average substrate cover between the control and impact sections before, $1 \mathrm{y}$ after, and $2 \mathrm{y}$ after wood additions. We averaged the results of the 3 randomly selected sections sam- pled/reach for further analyses. We tested changes in the spatial components of habitat structure by applying randomized intervention analysis (Carpenter et al. 1989) with Canoco (version 5.12; Wageningen University and Research, Wageningen, The Netherlands). We evaluated whether changes in physical structure occurred in impact reaches and compared these physical structure changes with those in the control reaches. We used 9999 Monte Carlo random permutations restricted to the temporal structure of the data (cyclic shifts) to calculate significance of the randomized intervention analysis. We tested the parameters with and without the large wood to determine if changes in physical structure in impact reaches were attributable to the presence of wood rather than to the presence of other substrate types.

Macroinvertebrates We used non-metric multidimensional scaling (NMDS) to visualize the changes in macroinvertebrate assemblages before and after the large-wood additions. To reduce distortion of assemblage differences by rare or highly abundant taxa, we only included taxa that were found more than once in these analyses, and we transformed abundances by $\log _{2}(x+1)$ in each sample. We based NMDS ordination on a Bray-Curtis dissimilarity matrix, and we used PC-ORD for Windows (version 4.25; MjM Software Design, Gleneden Beach, Oregon) with slow and thorough autopilot mode, 400 iterations, instability criterion of 0.00001 , 6 starting axes, 40 real runs, and 50 runs with randomized data (following manufacturer's instructions).

To obtain further insight into the changes in macroinvertebrate assemblages after wood additions, we used principal response curve (PRC) analysis in Canoco to analyze the macroinvertebrate data. This technique is based on redundancy analysis ordination, which is the constrained form of principal component analysis (van den Brink and ter Braak 1999). This technique results in a diagram in which time is displayed on the $\mathrm{x}$-axis, and the $1^{\text {st }}$ principal component (PRC-axis 1), which shows the treatment's effect on assemblage composition, is displayed on the y-axis. The diagram displays the deviations in assemblage composition over time in the impact sections compared with those in the control sections. The resulting taxon weights $\left(b_{\mathrm{k}}\right)$ indicate the fit between the response of the taxon and the overall assemblage response.

To obtain insight into the relationships between the addition of large wood and selected trait responses, we computed correlations between taxon functional and ecological trait scores with the PRC-derived taxon weights $\left(b_{\mathrm{k}}\right)$. Trait scores were fuzzy coded, whereby the scores ranged from 0 (avoidance) to 10 (strong preference) in each taxon. We calculated Spearman rank correlations for the mode-of-locomotion (semi-sessile) and feeding-type (passive filter feeder, shredder, predator, and scraper-grazer) categories (Schmidt-Kloiber and Hering 2015) and for the ecological trait scores for flow preference (high-flow velocity) and substrate preference (hard substrate and detritus) categories (Verberk et al. 2012). We 
included additional Chironomidae substrate preference data based on Moller Pillot (2009, 2013).

\section{RESULTS}

\section{Physical structure}

Before introduction of the large wood, stream beds were dominated by sand (Fig. 2). In the $1^{\text {st }} y$ after the wood additions, mean proportional cover of the different substrate types changed in the treatment sections compared with the control sections in all streams. When we included the proportion of wood in this analysis, the proportion of wood increased, and the proportional cover of the other substrate types also changed relative to each other. In streams Hierden and Tongelreep, the habitat diversity, complexity, and patchiness scores of the impact sections increased significantly

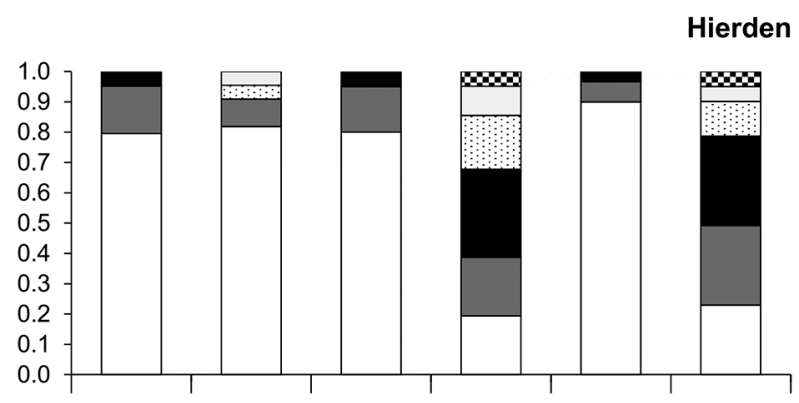

Tongelreep

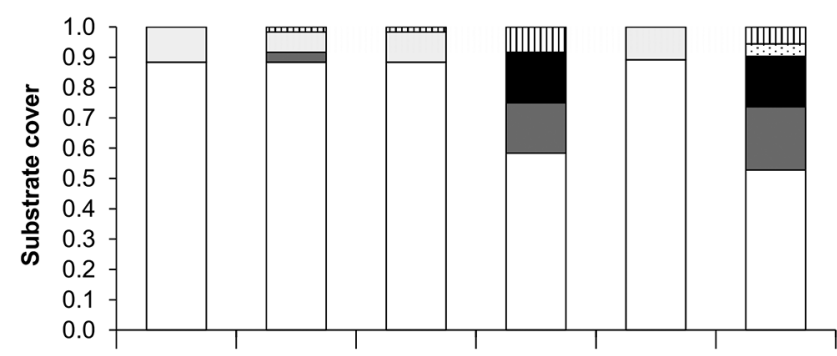

Tungelroy

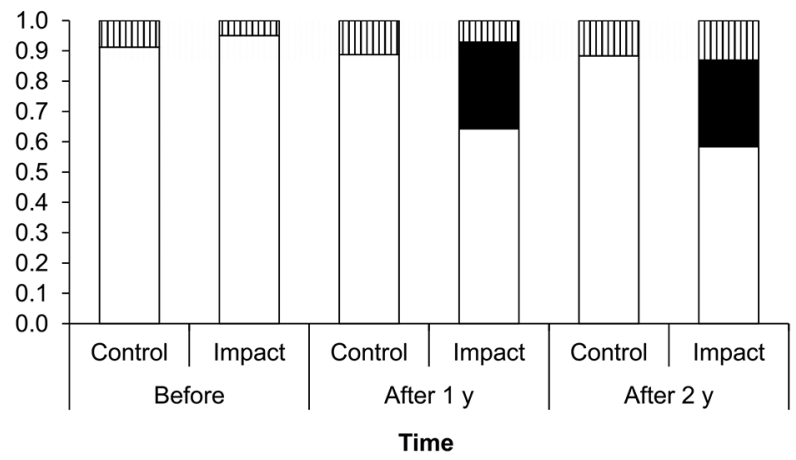

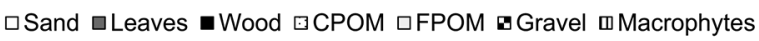

Figure 2. Mean substrate cover $(n=3)$ on a proportional cover scale (0-1) in the control and impact stream sections before, $1 \mathrm{y}$ after, and $2 \mathrm{y}$ after large-wood additions in streams Hierden, Tongelreep, and Tungelroy. after the large-wood introductions (Fig. 3A, B, Table 2). In stream Tungelroy the patchiness increased, but the other measures did not change in the treatment sections (Fig. 3C, Table 2). Excluding wood substrate from this analysis did not affect the outcome in stream Tongelreep, but in streams Hierden and Tungelroy the degree of patchiness became insignificant relative to the control reach. It appears that in stream Tungelroy, patchiness was primarily generated by the presence of the large wood and not by the other substrate types, as mean patchiness was similar to the control when large wood was excluded from the analysis. In contrast, the reason that we could not detect a difference in stream Hierden's patchiness, despite a mean that appeared to be different from the control, was because of a large amount of variability in the degree of patchiness of the other substrate types after excluding the large wood.

The initial similarity of proportional cover of streambed substrate types in the control and impact sections decreased (i.e., the Bray-Curtis dissimilarity increased) after the largewood additions, indicating an increase in substrate heterogeneity during the $1^{\text {st }} \mathrm{y}$ after the addition (Fig. 4). However, the difference in substrate heterogeneity between $1 \mathrm{y}$ and $2 \mathrm{y}$ after the wood additions was much smaller, indicating the proportional cover of the different substrate types had stabilized. Substrate coverage dissimilarity in stream Tungelroy was likely the result of the presence of large wood because excluding wood from the calculations led to an increase in similarity between the control and impact sections over time.

\section{Macroinvertebrates}

The optimal solution for NMDS of the macroinvertebrate assemblage composition resulted in 3 axes for all streams (Fig. 5A-C). Macroinvertebrate assemblages were distinct relative to the controls after the wood additions. Dissimilarity differed among streams, and stream Tongelreep had the largest deviation in assemblage composition between control and treatment sections. Additionally, the different sampling years were clearly separated in the diagram, especially in stream Hierden, indicating that time had a large effect on assemblage composition.

PRC showed that before the introduction of the large wood, control-impact differences in macroinvertebrate assemblage composition were relatively small (Fig. 6). After the large-wood additions, assemblage composition changed more in the treatment sections than in the control sections (Monte Carlo permutation tests, PRC-axis 1: Hierden$14.8 \%$ of the variation in assemblage composition explained by treatment, $F=0.7, p=0.03$; Tongelreep-25.3\%, $F=1.4$, $p=0.002$; Tungelroy-16.3\%, $F=0.8, p=0.01$ ). The smaller differences between treatments and controls in streams Hierden and Tungelroy in the $2^{\text {nd }} y$ relative to the $1^{\text {st }} y$ after treatment indicates that the effect of wood introduction in these streams decreased over time. In stream Tongelreep, however, a further increase was observed, indicating an even 


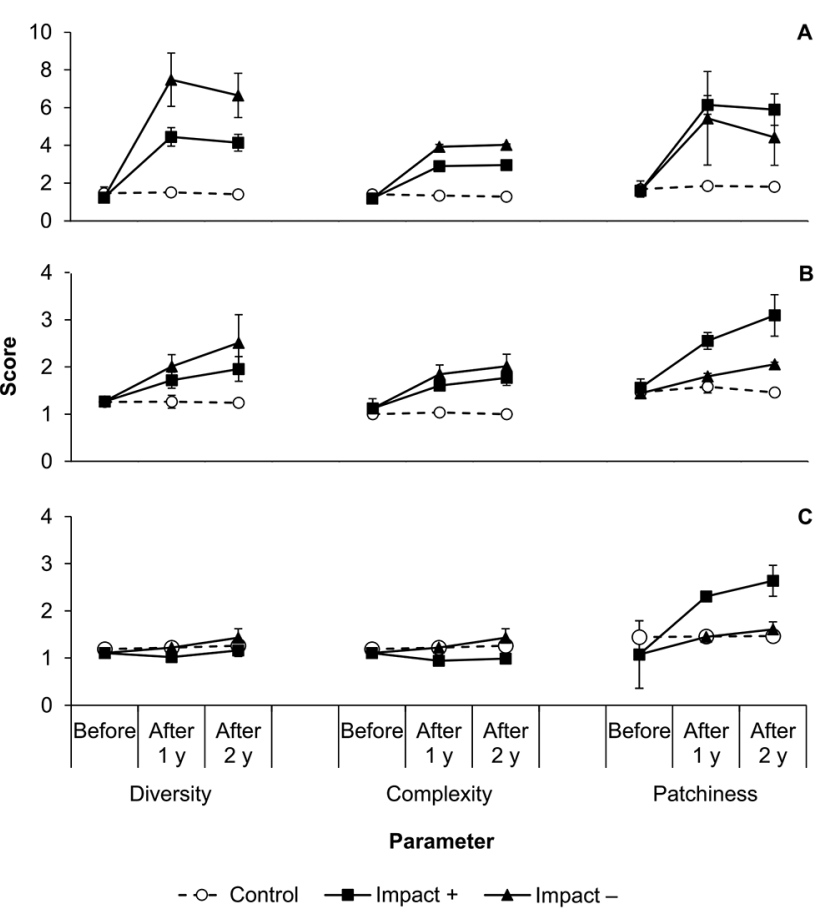

Figure 3. Mean $( \pm \mathrm{SD})$ diversity, complexity, and patchiness scores in the control and impact reaches before, $1 \mathrm{y}$ after, and $2 \mathrm{y}$ after the large-wood additions in streams Hierden (A), Tongelreep (B), and Tungelroy (C). To make clear which changes occurred because of the added wood, both the results including $(+)$ and excluding $(-)$ the large wood as 1 of the components of physical structure are shown.

larger effect of large-wood additions in the $2^{\text {nd }} y$ as compared with the $1^{\text {st }} \mathrm{y}$.

PRC taxon weights indicate the fit between the response of the observed taxa and the overall assemblage response (Table S1). In total, $\sim 1 / 2$ of the taxa (51-58\%) displayed an increase $\left(b_{\mathrm{k}}>0.5\right)$ or decrease $\left(b_{\mathrm{k}}<-0.5\right)$ in abundance after the wood addition. In stream Hierden (41 total taxa), 16 taxa increased in abundance and 5 taxa decreased. In stream Tongelreep (54 total taxa), 26 taxa increased and only 2 taxa decreased. In stream Tungelroy (55 total taxa), 16 taxa increased and 16 taxa decreased after the largewood additions.

The species that increased markedly in response to the wood additions in all streams were caddisflies Hydropsyche pellucidula and Lype reducta/phaeopa as well as blackflies Simulium spp. $\left(b_{\mathrm{k}}>2\right)$. In stream Hierden the caddisfly Polycentropus irroratus and the whirligig beetle Orectochilus villosus also increased markedly. In stream Tongelreep the amphipod Echinogammarus berilloni and the damselfly Calopteryx splendens increased markedly. More taxa decreased in abundance in stream Tungelroy than in the other 2 streams, and these ranged from the caddisflies Neureclipsis bimaculata and Mystacides spp., the mayfly Cloeon dipterum, the chironomid Microtendipes spp., and the bivalve Corbicula fluminea.
We correlated the ecological and functional trait parameters to the taxon weights derived from the PRC analyses, which showed that the responses of the macroinvertebrate assemblages were related to their affinity for hard substrate in all streams (Table 3). No further relationships with the functional traits were found in streams Hierden and Tungelroy. In stream Tongelreep the addition of large wood matched an increase in the affinity for high-flow velocity and a scrapergrazer feeding type.

\section{DISCUSSION}

Habitat heterogeneity has been shown to increase after the introduction of large wood in various stream types (Gerhard and Reich 2000, Lester and Boulton 2008, Pilotto et al. 2014, 2016), and our study is no exception. Here, large-wood introductions resulted in an increase in habitat heterogeneity because the degree of streambed substrate patchiness increased overall, and, in Hierden and Tongelreep, we observed a subsequent increase in substrate diversity and complexity. Furthermore, the degree of change in proportional cover of the different substrate types was smaller in the $2^{\text {nd }} y$ after the wood introduction, so the increased diversity of streambed substrates appeared relatively stable. Microscale macroinvertebrate distribution is closely related to streambed substrate patterns and is largely determined by the functions the patches provide, such as flow refugium, aggregation of food resources, or oviposition/pupation sites (Tolkamp 1982, Lancaster 1999). Our results support the idea that habitat heterogeneity could be an important step toward restoration of degraded stream ecosystems through promoting species diversity via niche and resource availability (Tews et al. 2004) as well as via ecosystem functioning and service provisioning (Frainer et al. 2018).

Table 2. Before-after control-impact (BACI) analyses on physicalstructure spatial components with Monte Carlo permutation tests (9999 permutations) based on dependent random shifts of the time series. Tests of the structural metrics in the reaches where wood patches were introduced were computed both with $(+)$ and without (-) the large wood (LW) to detect whether changes were caused by the other substrate types. Reported values are $F$-statistics and $p$-values.

\begin{tabular}{|c|c|c|c|c|c|c|c|}
\hline \multirow[b]{2}{*}{ Site } & \multirow[b]{2}{*}{ LW } & \multicolumn{2}{|c|}{ Diversity } & \multicolumn{2}{|c|}{ Complexity } & \multicolumn{2}{|c|}{ Patchiness } \\
\hline & & $F$ & $p$ & $F$ & $p$ & $F$ & $p$ \\
\hline \multirow[t]{2}{*}{ Hierden } & + & 46.9 & 0.026 & 84.7 & 0.021 & 44.8 & 0.033 \\
\hline & - & 29.5 & 0.019 & 186.0 & 0.017 & 3.8 & 0.137 \\
\hline \multirow[t]{2}{*}{ Tongelreep } & + & 9.4 & 0.047 & 11.6 & 0.015 & 19.3 & 0.003 \\
\hline & - & 8.0 & 0.044 & 13.1 & 0.024 & 35.0 & 0.003 \\
\hline \multirow[t]{2}{*}{ Tungelroy } & + & 0.6 & 0.449 & 2.9 & 0.127 & 8.9 & 0.014 \\
\hline & - & 2.8 & 0.070 & 2.8 & 0.070 & 1.4 & 0.323 \\
\hline
\end{tabular}




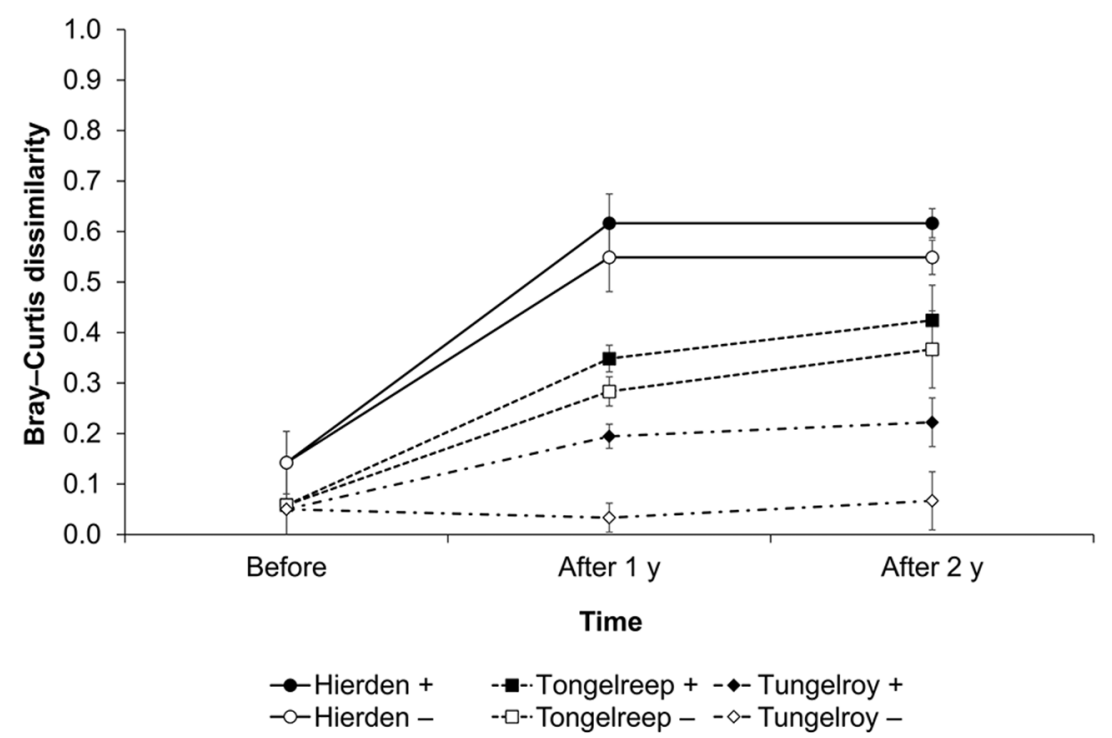

Figure 4. Stability of the streambed substrate coverage, expressed as Bray-Curtis dissimilarity of the mean ( \pm SD) substrate composition between control and impact stream sections before, 1 y after, and 2 y after introduction of large wood. To make clear which changes occurred because of the added wood, both the results including $(+)$ and excluding $(-)$ the large wood as 1 of the components of physical structure are shown.

The differential responses in substrate diversity and complexity we observed among the 3 streams were probably because of large site-specific or regional factors. Stream Hierden has a large amount of gravel in the stream subsurface, which leads to faster formation of gravel beds when wood is introduced because sand is washed away by increased flow. Gravel substrate was not present in this stream before restoration, so addition of this new substrate type likely led to the increase in substrate diversity. In addition, Tungelroy, which did not increase in substrate diversity or complexity, runs through a more-open, grasslanddominated landscape than Hierden and Tongelreep, both of which run through forested watersheds. Leaf retention diversifies the substrate composition of streams (Muotka and
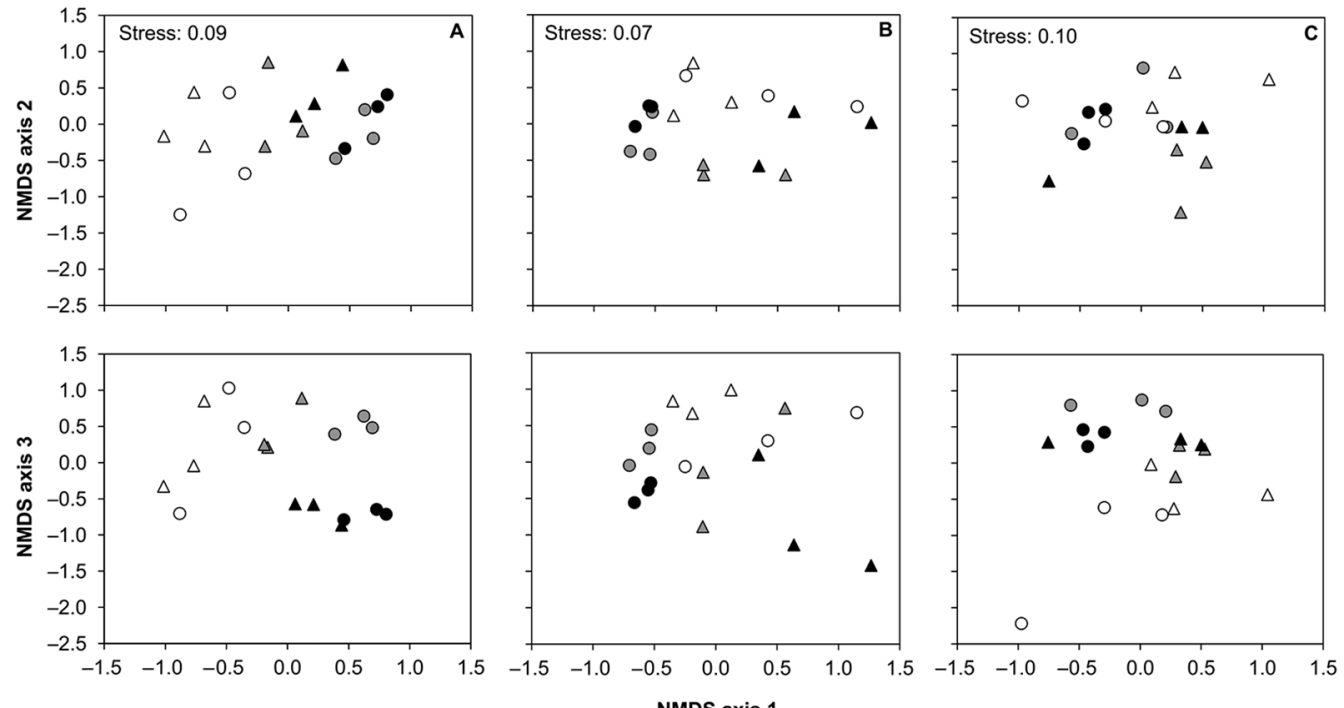

$\begin{array}{lll}\triangle \text { Control before } & \text { Olmpact before } & \Delta \text { Control after 1 y } \\ \text { OImpact after 1y } & \Delta \text { Control after 2y } & \bullet \text { Impact after 2 y }\end{array}$

Figure 5. Non-metric multidimensional scaling plots of macroinvertebrate assemblages in the control and impact sections of streams Hierden (A), Tongelreep (B), and Tungelroy $(C)$ before and after the introduction of large wood $(n=3 / y)$ based on BrayCurtis dissimilarities. 


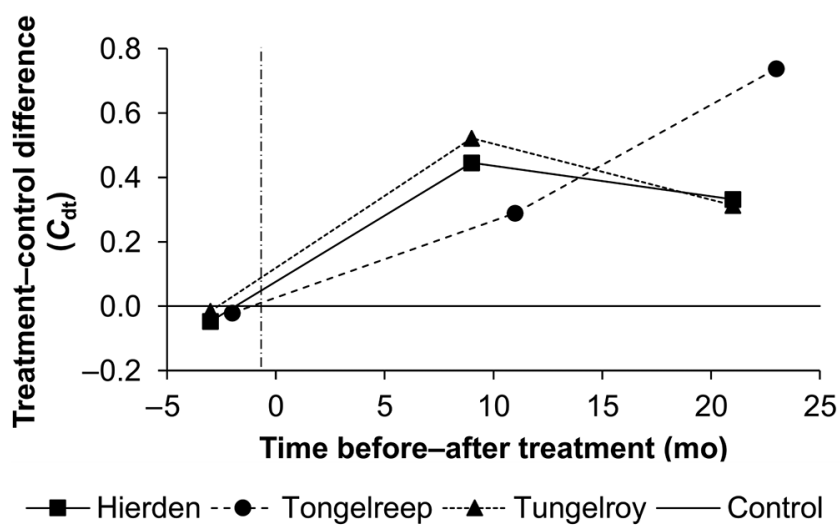

Figure 6. Principal response curves of treatment effects $\left(C_{\mathrm{d} t}, \mathrm{PRC}\right.$-axis 1$)$ on the macroinvertebrate assemblages for the 3 streams. The lines represent the effect of treatment over time, and each point represents the mean of 3 sections/y. Zero (vertical broken line) represents the time at which wood was added to the streams.

Laasonen 2002), so the allochthonous inputs of large quantities of CPOM (especially leaves) into stream Hierden, and to a lesser extent into stream Tongelreep, may have acted as a catalyst for streambed diversification in and around the large-wood patches. These allochthonous inputs were probably smaller in stream Tungelroy, where the density of riparian trees was much lower. Additionally, stream Tungelroy's larger channel width and depth may have decreased the trapping efficiency of allochthonous organic matter inputs (Raikow et al. 1995, Larrañaga et al. 2003). Finally, stream Tungelroy has steep banks and high turbidity, which might not allow for the macrophyte development that is common in unshaded streams. If present, these macrophyte stands could have acted as an autochthonous source of organic material, especially during autumn senescence, contributing to an increase in patch substrate diversity and structural complexity.

Rapid recolonization of macroinvertebrates from local habitat sources has been found in other lowland streams (Westveer et al. 2018), which is consistent with our results. Macroinvertebrate assemblages changed in all streams, es- pecially in the $1^{\text {st }} \mathrm{y}$ after the wood additions when many taxa increased in abundance. Taxa that increased after the wood additions showed a strong affinity for hard substrates. Prior to the wood reintroduction, hard substrates were sparse and mostly consisted of tree roots protruding into the stream channel. We expect that these local structures were the primary source of macroinvertebrate colonists that settled on the introduced large wood.

Temporal differences in macroinvertebrate assemblages could be a function of regional species pools. In streams Hierden and Tungelroy, differences in macroinvertebrate assemblage composition in sections with woody additions compared with control sections did not change significantly between the $1^{\text {st }}$ and $2^{\text {nd }} y$, but in stream Tongelreep the difference further increased in the $2^{\text {nd }} y$. Limited availability of species within the regional species pool (Spänhoff and Arle 2007, Tonkin et al. 2014) might explain the lack of response in the $2^{\text {nd }} \mathrm{y}$ because if all species present in a stream section colonized the wood during the $1^{\text {st }} \mathrm{y}$, no new species would be available to colonize the wood during the $2^{\text {nd }} y$. If regional colonization is the main mechanism of assemblage on large wood in the lowland streams we studied, it would suggest that the potential number of colonists is higher in stream Tongelreep in comparison to the other 2 streams. This potential effect of existing assemblage diversity on temporal colonization patterns would be an interesting question for future research.

Associations between the addition of large wood and functional and ecological traits of macroinvertebrates may offer additional insight into the potential for stream restoration to influence macroinvertebrate assemblage composition. In stream Tongelreep, a preference for high-flow velocity and a grazer-scraper feeding mode were associated with large wood or the presence of hard surfaces in general. Pieces of wood that protrude into the water column are exposed to higher flow velocities than the wood pieces or leaf packs that sit on the stream bottom (Schoen et al. 2013, Pilotto et al. 2016) and provide hydraulic conditions suitable for colonization by invertebrates preferring high-flow areas. In addition, scrapers feed on the epixylic biofilm present on the surfaces of submerged wood (Benke and Wallace 2003). The

Table 3. Spearman rank correlations $(\rho)$ between the taxon weights of the macroinvertebrate assemblages recorded in the streams, which indicate the response of the individual taxa to the introduction of large wood and the ecological- and functional-trait-category affinities for these taxa. $p$-values in bold are $<0.05$.

\begin{tabular}{|c|c|c|c|c|c|c|c|c|c|c|c|c|c|c|c|c|}
\hline \multirow[b]{3}{*}{ Site } & \multicolumn{16}{|c|}{ Trait category } \\
\hline & \multicolumn{2}{|c|}{ Detritus } & \multicolumn{2}{|c|}{$\begin{array}{c}\text { Hard } \\
\text { substrate }\end{array}$} & \multicolumn{2}{|c|}{$\begin{array}{l}\text { Semi- } \\
\text { sessile }\end{array}$} & \multicolumn{2}{|c|}{$\begin{array}{l}\text { Grazer/ } \\
\text { scraper }\end{array}$} & \multicolumn{2}{|c|}{ Shredder } & \multicolumn{2}{|c|}{$\begin{array}{l}\text { Passive } \\
\text { filter feeder }\end{array}$} & \multicolumn{2}{|c|}{ Predator } & \multicolumn{2}{|c|}{$\begin{array}{l}\text { High flow } \\
\text { velocity }\end{array}$} \\
\hline & $\rho$ & $p$ & $\rho$ & $p$ & $\rho$ & $p$ & $\rho$ & $p$ & $\rho$ & $p$ & $\rho$ & $p$ & $\rho$ & $p$ & $\rho$ & $p$ \\
\hline Hierden & -0.18 & 0.33 & 0.46 & 0.01 & 0.19 & 0.32 & 0.13 & 0.46 & -0.31 & 0.06 & 0.25 & 0.14 & 0.06 & 0.72 & 0.18 & 0.30 \\
\hline Tongelreep & -0.23 & 0.12 & 0.33 & 0.02 & 0.10 & 0.53 & 0.32 & 0.02 & 0.17 & 0.23 & 0.26 & 0.07 & -0.06 & 0.71 & 0.42 & $<0.01$ \\
\hline Tungelroy & 0.10 & 0.50 & 0.32 & 0.02 & -0.09 & 0.56 & 0.25 & 0.08 & 0.13 & 0.37 & 0.04 & 0.77 & -0.18 & 0.21 & 0.21 & 0.13 \\
\hline
\end{tabular}


availability of both submerged-wood surfaces and habitat in high-flow conditions was limited in these streams before introduction of large wood. Thus, wood additions increased the habitat and resource availability for macroinvertebrates with these traits. Why this preference for high-flow velocity and a grazer-scraper feeding mode was not found in the other 2 streams, as well as an overall lack of response in the other large-wood-related functional traits, passive filterfeeder and predator feeding groups, and a semi-sessile mode of locomotion, is unknown. In general, functional feeding groups have shown variable responses to large-wood additions in different studies, probably because of site-specific environmental conditions (e.g., Johnson et al. 2003, Lester et al. 2007).

In addition to the presence of large wood in streams, the age of large-wood patches might be important in influencing both substrate characteristics and macroinvertebrate assemblage composition (Benke and Wallace 2003). We only studied large-wood patches that were submerged for $<2 \mathrm{y}$, and wood of this age might not provide the full spectrum of resources and functions that come with time. This lack of long-term data could be an explanation for why we did not observe responses in taxa with a preference for detritus patches or in the shredder functional feeding group. Large-wood patches accumulate organic material over time, including leaves, seeds, and small branches, because of their retention capacity and stability, but these accumulations may require years to develop (Jones 1997, Tank et al. 2010). Over time these organic patches become a mixture of organic particles at different stages of decomposition or abrasion toward the center of the patch and, thus, of different food and habitat quality for macroinvertebrates. Further, the surface texture of the wood changes over time because of abrasion or decay, which could potentially influence macroinvertebrate assemblage composition (Molokwu et al. 2014).

Our findings suggest that the main beneficial effect of reintroducing large wood to the stream channel of sandbed lowland streams is the provisioning of stable habitat substrate or surface but that this change may only affect specific portions of the local macroinvertebrate assemblage. However, we studied only the short-term effect of wood additions at an early stage of development of wood structures and their associated substrates. The relative contribution of the wood patches in determining the taxonomic and functional composition of the assemblage might change as the wood patches age. At the same time, aging of the patches may not lead to substantial assemblage changes if the number of potential colonists is limited by a degraded species pool at the stream-to-catchment scale (Leps et al. 2016). Future research should include long-term repeated sampling of the macroinvertebrate assemblages that inhabit introduced large-wood patches to disentangle the effects of environmental conditions from those related to the size of the regional species pool.

\section{ACKNOWLEDGEMENTS}

Author contributions: JHFDB was involved in the study design, acquired and analyzed data, and wrote parts of the manuscript text. PFMV was involved in the study design, analyzed data, and critically revised the manuscript. JPCE was involved in the study design, acquired data, and added to the revision of the manuscript. RCMV analyzed data and wrote parts of the manuscript text.

We thank Waterboard Vallei en Veluwe, Waterboard Limburg, and Waterboard De Dommel for their support involving, amongst others, the site selection and large-wood placement and Dorine Dekkers for assistance with identifying the invertebrate samples. We are also grateful to 2 anonymous reviewers and the associate editor K. Gido who provided helpful comments that improved previous versions of the manuscript.

This project was funded by Agentschap NL (KRW09023) and the Foundation for Applied Water Research (STOWA-443243) to JHFDB, JPCE, and PFMV and supported by the Knowledge Network for Restoration and Management of Nature in the Netherlands (OBN 2016-83-BE) to RCMV and PFMV.

\section{LITERATURE CITED}

Angermeier, P. L., and J. R. Karr. 1984. Relationships between woody debris and fish habitat in a small warmwater stream. Transactions of the American Fisheries Society 113:716-726.

Benke, A. C., and J. B. Wallace. 2003. Influence of wood on invertebrate communities in streams and rivers. Pages 149-177 in S. V. Gregory, K. L. Boyer, and A. M. Gurnell (editors). The ecology and management of wood in world rivers. American Fisheries Society, Symposium 37, Bethesda, Maryland.

Carpenter, S. R., T. M. Frost, D. Heisey, and T. K. Kratz. 1989. Randomized intervention analysis and the interpretation of whole-ecosystem experiments. Ecology 70:1142-1152.

Collier, K. J., and J. N. Halliday. 2000. Macroinvertebrate-wood associations during decay of plantation pine in New Zealand pumice-bed streams: Stable habitat or trophic subsidy? Journal of the North American Benthological Society 19:94-111.

Eadie, J. M., and A. Keast. 1984. Resource heterogeneity and fish species diversity in lakes. Canadian Journal of Zoology 62:16891695.

Frainer, A., L. E. Polvi, R. Jansson, and B. G. McKie. 2018. Enhanced ecosystem functioning following stream restoration: The roles of habitat heterogeneity and invertebrate species traits. Journal of Applied Ecology 55:377-385.

Gerhard, M., and M. Reich. 2000. Restoration of streams with large wood: Effects of accumulated and built-in wood on channel morphology, habitat diversity and aquatic fauna. International Review of Hydrobiology 85:123-137.

Gippel, C. J. 1995. Environmental hydraulics of large woody debris in streams and rivers. Journal of Environmental Engineering 121:388-395.

Gippel, C. J., I. C. O’Neill, B. L. Finlayson, and I. N. G. O. Schnatz. 1996. Hydraulic guidelines for the reintroduction and management of large woody debris in lowland rivers. Regulated Rivers Research and Management 12:223-236.

Grabowski, R. C., A. M. Gurnell, L. Burgess-Gamble, J. England, D. Holland, M. J. Klaar, I. Morrissey, C. Uttley, and G. Wharton. 2019. The current state of the use of large wood in river restoration and management. Water and Environment Journal 33:366-377. 
Gurnell, A. M., H. Piégay, F. J. Swanson, and S. V. Gregory. 2002. Large wood and fluvial processes. Freshwater Biology 47:601-619.

Harmon, M. E., J. F. Franklin, F. J. Swanson, P. Sollins, S. V. Gregory, J. D. Lattin, N. H. Anderson, S. P. Cline, N. G. Aumen, J. R. Sedell, and G. W. Lienkaemper. 1986. Ecology of coarse woody debris in temperate ecosystems. Advances in Ecological Research 15:133-302.

Hax, C. L., and S. W. Golladay. 1998. Flow disturbance of macroinvertebrates inhabiting sediments and woody debris in a prairie stream. American Midland Naturalist 139:210-223.

Hering, D., A. Buffagni, O. Moog, L. Sandin, M. Sommerhäuser, I. Stubauer, C. Feld, R. Johnson, P. Pinto, N. Skoulikidis, P. Verdonschot, and S. Zahrádková. 2003. The development of a system to assess the ecological quality of streams based on macroinvertebrates-Design of the sampling programme within the AQEM project. International Review of Hydrobiology 88:345-361.

Hering, D., O. Moog, L. Sandin, and P. F. M. Verdonschot. 2004. Overview and application of the AQEM assessment system. Hydrobiologia 516:1-20.

Hill, M. O. 1973. Diversity and evenness: A unifying notation and its consequences. Ecology 54:427-432.

Johnson, L. B., D. H. Breneman, and C. Richards. 2003. Macroinvertebrate community structure and function associated with large wood in low gradient streams. River Research and Applications 19:199-218.

Jones, J. B. 1997. Benthic organic matter storage in streams: Influence of detrital import and export, retention mechanisms, and climate. Journal of the North American Benthological Society 16:109-119.

Kail, J., D. Hering, S. Muhar, M. Gerhard, and S. Preis. 2007. The use of large wood in stream restoration: Experiences from 50 projects in Germany and Austria. Journal of Applied Ecology 44:1145-1155.

Koljonen, S., P. Louhi, A. Mäki-Petäys, A. Huusko, and T. Muotka. 2012. Quantifying the effects of in-stream habitat structure and discharge on leaf retention: Implications for stream restoration. Freshwater Science 31:1121-1130.

Lancaster, J. 1999. Small-scale movements of lotic macroinvertebrates with variations in flow. Freshwater Biology 41:605-619.

Larrañaga, S., J. R. Díez, E. Elosegi, and J. Pozo. 2003. Leaf retention in streams of the Agüera basin (northern Spain). Aquatic Sciences 65:158-166.

Lepori, F., D. Palm, and B. Malmqvist. 2005. Effects of stream restoration on ecosystem functioning: Detritus retentiveness and decomposition. Journal of Applied Ecology 42:228-238.

Leps, M., A. Sundermann, J. D. Tonkin, A. W. Lorenz, and P. Haase. 2016. Time is no healer: Increasing restoration age does not lead to improved benthic invertebrate communities in restored river reaches. Science of the Total Environment 557-558:722-732.

Lester, R. E., and A. J. Boulton. 2008. Rehabilitating agricultural streams in Australia with wood: A review. Environmental Management 42:310-326.

Lester, R. E., W. Wright, and M. Jones-Lennon. 2007. Does adding wood to agricultural streams enhance biodiversity? An experimental approach. Marine and Freshwater Research 58:687-698.

Moller Pillot, H. K. M. 2009. Chironomidae larvae, volume 2: Chironomini: Biology and ecology of the Chironomini. KNNV Publishing, Zeist, The Netherlands.
Moller Pillot, H. K. M. 2013. Chironomidae larvae, volume 3: Orthocladiinae: Biology and ecology of the aquatic Orthocladiinae. KNNV Publishing, Zeist, The Netherlands.

Molokwu, N. D., P. G. Vaz, T. Bradshaw, A. Blake, C. Henessey, and E. Merten. 2014. Effects of substrate on the benthic macroinvertebrate community: An experimental approach. Ecological Engineering 73:109-114.

Muotka, T., and P. Laasonen. 2002. Ecosystem recovery in restored headwater streams: The role of enhanced leaf retention. Journal of Applied Ecology 39:145-156.

Pilotto, F., A. Bertoncin, G. L. Harvey, G. Wharton, and M. T. Pusch. 2014. Diversification of stream invertebrate communities by large wood. Freshwater Biology 59:2571-2583.

Pilotto, F., G. L. Harvey, G. Wharton, and M. T. Pusch. 2016. Simple large wood structures promote hydromorphological heterogeneity and benthic macroinvertebrate diversity in lowgradient rivers. Aquatic Sciences 78:755-766.

Raikow, D. F., S. A. Grubbs, and K. W. Cummins. 1995. Debris dam dynamics and coarse particulate organic matter retention in an Appalachian mountain stream. Journal of the North American Benthological Society 14:535-546.

Roni, P., T. Beechie, G. Pess, and K. Hanson. 2015. Wood placement in river restoration: Fact, fiction, and future direction. Canadian Journal of Fisheries and Aquatic Sciences 72:466-478.

Scealy, J. A., S. J. Mika, and A. J. Boulton. 2007. Aquatic macroinvertebrate communities on wood in an Australian lowland river: Experimental assessment of the interactions of habitat, substrate complexity and retained organic matter. Marine and Freshwater Research 58:153-165.

Schinegger, R., C. Trautwein, A. Melcher, and S. Schmutz. 2012. Multiple human pressures and their spatial patterns in European running waters. Water and Environment Journal 26:261-273.

Schmidt-Kloiber, A., and D. Hering. 2015. www.freshwaterecol ogy.info-An online tool that unifies, standardises and codifies more than 20,000 European freshwater organisms and their ecological preferences. Ecological Indicators 53:271-282.

Schoen, J., E. Merten, and T. Wellnitz. 2013. Current velocity as a factor in determining macroinvertebrate assemblages on wood surfaces. Journal of Freshwater Ecology 28:271-275.

Spänhoff, B., and J. Arle. 2007. Setting attainable goals of stream habitat restoration from a macroinvertebrate view. Restoration Ecology 15:317-320.

Tank, J. L., E. J. Rosi-Marshall, N. A. Griffiths, S. A. Entrekin, and M. L. Stephen. 2010. A review of allochthonous organic matter dynamics and metabolism in streams. Journal of the North American Benthological Society 29:118-146.

Tews, J., U. Brose, V. Grimm, K. Tielbörger, M. C. Wichmann, M. Schwager, and F. Jeltsch. 2004. Animal species diversity driven by habitat heterogeneity/diversity: The importance of keystone structures. Journal of Biogeography 31:79-92.

Tolkamp, H. H. 1982. Microdistribution of macroinvertebrates in lowland streams. Hydrobiological Bulletin 16:133-148.

Tonkin, J. D., S. Stoll, A. Sundermann, and P. Haase. 2014. Dispersal distance and the pool of taxa, but not barriers, determine the colonisation of restored river reaches by benthic invertebrates. Freshwater Biology 59:1843-1855.

van den Brink, P. J., and C. J. F. ter Braak. 1999. Principal response curves: Analysis of time-dependent multivariate responses of biological community to stress. Environmental Toxicology and Chemistry 18:138-148. 
van der Molen, D. T., R. Pot, C. H. M. Evers, F. C. J. van Herpen, and L. L. J. van Nieuwerburgh (editors). 2019. Referenties en maatlatten voor natuurlijke watertypen voor de Kaderrichtlijn Water 2021-2027. STOWA Report 2018-49. STOWA, Ministerie van Infrastructuur en Waterstaat, Amersfoort, The Netherlands. (Available from: https://www.stowa.nl/publicaties/referenties -en-maatlatten-voor-natuurlijke-watertypen-voor-de-kader richtlijn-water-2021)

Verberk, W. C. E. P., P. F. M. Verdonschot, T. van Haaren, and B. van Maanen. 2012. Milieu-en habitatpreferenties van Nederlandse zoetwatermacrofauna. WEW Themanummer 23. STOWA Report 2012-19. Werkgroep Ecologisch Waterbeheer subgroep Autecologie, Van de Garde-Jémé, Eindhoven, The Netherlands. (Available from: https://www.stowa.nl/publicaties/milieu-en -habitatpreferenties-nederlandse-zoetwatermacrofauna)

Westveer, J. J., H. G. van der Geest, E. E. van Loon, and P. F. M. Verdonschot. 2018. Connectivity and seasonality cause rapid taxonomic and functional trait succession within an invertebrate community after stream restoration. PLoS ONE 13:e0197182. 